\title{
Properties of Aluminum Doped Zinc Oxide Thin Film Prepared by Sol-gel Process
}

\author{
Sung-Hak Yi, Jin-Yeol Kim and Woo-Gwang Jung \\ School of Advanced Materials Engineering, Kookmin University Seoul, 136-702, Korea
}

(Received June 2, 2010 : Received in revised form June 25, 2010 : Accepted June 25, 2010)

\begin{abstract}
Transparent conducting aluminum-doped $\mathrm{ZnO}$ thin films were deposited using a sol-gel process. In this study, the important deposition parameters were investigated thoroughly to determine the appropriate procedures to grow large area thin films with low resistivity and high transparency at low cost for device applications. The doping concentration of aluminum was adjusted in a range from 1 to $4 \mathrm{~mol} \%$ by controlling the precursor concentration. The annealing temperatures for the pre-heat treatment and post-heat treatment was $250^{\circ} \mathrm{C}$ and $400-600^{\circ} \mathrm{C}$, respectively. The SEM images show that $\mathrm{Al}$ doped and undoped $\mathrm{ZnO}$ films were quite uniform and compact. The XRD pattern shows that the $\mathrm{Al}$ doped $\mathrm{ZnO}$ film has poorer crystallinity than the undoped films. The crystal quality of $\mathrm{Al}$ doped $\mathrm{ZnO}$ films was improved with an increase of the annealing temperature to $600^{\circ} \mathrm{C}$. Although the structure of the aluminum doped $\mathrm{ZnO}$ films did not have a preferred orientation along the (002) plane, these films had high transmittance $(>87 \%)$ in the visible region. The absorption edge was observed at approximately $370 \mathrm{~nm}$, and the absorption wavelength showed a blue-shift with increasing doping concentration. The $\mathrm{ZnO}$ films annealed at $500^{\circ} \mathrm{C}$ showed the lowest resistivity at $1 \mathrm{~mol} \% \mathrm{Al}$ doping.
\end{abstract}

Key words $\underline{\mathrm{ZnO} \text { thin film, }}$ Al doping, sol-gel, transmittance, electric conductivity, transparent conducting oxide film.

\section{Introduction}

$\mathrm{ZnO}$, a representative II-VI group compound semiconductor with a wide direct band gap $(3.37 \mathrm{eV})$ and large exciton binding energy $(60 \mathrm{meV})$, is a good candidate as an excellent electronic and photonic material for solar cells, ${ }^{1)}$ light-emitting diodes, ${ }^{2)}$ photodetectors ${ }^{3)}$ and gas sensors. ${ }^{4)}$ Recently, $\mathrm{ZnO}$ has attracted considerable interest as a transparent conducting oxide film (TCO). ${ }^{5)}$ Transparent conducting oxide films have applications in optoelectronic devices, such as solar cells ${ }^{6,7)}$ and heat mirrors. ${ }^{8)}$ Doped $\mathrm{ZnO}$ film has high chemical stability, abundance in nature, and lower cost than the most currently used transparent conducting oxide materials, indium tin oxide (ITO) and $\mathrm{SnO}_{2}$. In addition, doping in $\mathrm{ZnO}$ increases the film conductivity. Higher valence elements, such as indium (In), $\left.{ }^{9}\right)$ gallium (Ga), ${ }^{10)}$ aluminum (Al), ${ }^{5)}$ can be doping elements in $\mathrm{ZnO}$ film. Many techniques have been used to deposit undoped and doped $\mathrm{ZnO}$ thin films on a range of substrates, including spray pyrolysis, ${ }^{10)}$ metal-organic chemical vapor deposition (MOCVD), ${ }^{3)}$ pulsed laser deposition (PLD), ${ }^{11)}$ molecular beam epitaxy (MBE), ${ }^{12)}$ radio frequency magnetron sputtering, ${ }^{13)}$ atomic layer deposition (ALD) ${ }^{14)}$ and solgel process. ${ }^{15)}$ Among them, sol-gel processes have attracted increasing attention because it enables the development of

${ }^{\dagger}$ Corresponding author

E-Mail : wgjung@kookmin.ac.kr (W. -G. Jung) low cost and simple deposition procedures to obtain high quality transparent conducting oxide films. Although thin films obtained by physical deposition, such as pulsed laser deposition (PLD) and radio frequency magnetron sputtering, exhibit good optical and electrical properties at lower deposition temperatures, the relatively low deposition rate and high equipment cost are significant disadvantages. In this sense, the sol-gel process is a rather efficient technique for depositing aluminum doped $\mathrm{ZnO}$ (AZO) films over large areas at low cost for technological applications.

In this study, aluminum doped $\mathrm{ZnO}$ films were grown on $\mathrm{Si}$ and glass substrates by spin coating using zinc acetate, Al nitrate and 2-methoxyethanol as the precursors, and monoethanolamine (MEA) as the stabilizer. The dopant concentration was varied from 1 to $4 \mathrm{~mol} \%$. The film was preheated at $250^{\circ} \mathrm{C}$ for $5 \mathrm{~min}$ and post-heated in an ambient atmosphere at several temperatures ranging from 400 $600^{\circ} \mathrm{C}$ for $30 \mathrm{~min}$. The effects of the doping concentration and thermal treatment on the structure, electrical and optical properties of the $\mathrm{ZnO}$ films were investigated. The structural characteristics were examined by XRD and FE-SEM. The electrical and optical properties were investigated measuring the resistivity and transmittance in the visible and near infrared wavelength region.

\section{Experimental Procedure}

Al doped $\mathrm{ZnO}$ films were prepared using a sol-gel 
process. Zinc acetate dihydrate $\left(\mathrm{Zn}\left(\mathrm{CH}_{3} \mathrm{COOH}\right)_{2} \cdot 2 \mathrm{H}_{2} \mathrm{O}\right)$ was used as the starting precursor material. 2-methoxyethanol $\left(\mathrm{CH}_{3} \mathrm{OC}_{2} \mathrm{H}_{4} \mathrm{OH}\right)$ and MEA $\left(\mathrm{H}_{2} \mathrm{NCH}_{2} \mathrm{CH}_{2}-\mathrm{OH}\right)$ were used as the solvent and stabilizer, respectively. Aluminum nitrate hexahydrate $\left(\mathrm{Al}\left(\mathrm{NO}_{3}\right)_{2} \cdot 6 \mathrm{H}_{2} \mathrm{O}\right)$ was used as the doping source. The process does not include special hydrolysis. Zinc acetate dihydrate and aluminum nitrate hexahydrate were first dissolved in mixture of 2-methoxyethanol and MEA solution at room temperature. The precursor solution was mixed thoroughly with a magnetic stirrer. The dopant concentration, as determined by $[\mathrm{Al}(\mathrm{mol})] /[\mathrm{Al}(\mathrm{mol})+\mathrm{Zn}$ $(\mathrm{mol})] \times 100$, was varied from 1 to $4 \mathrm{~mol} \%$. MEA was used to increase the solubility of zinc acetate dihydrate. The MEA to zinc acetate dihydrate molar ratio was 1 , and the zinc acetate dihydrate concentration was $0.2 \mathrm{M}$. The solution was stirred at $60^{\circ} \mathrm{C}$ for $2 \mathrm{~h}$ until it became clear and homogeneous, and then cooled to room temperature. The solution was spin coated on a Si substrate and glass in the $1^{\text {st }}$ step at $500 \mathrm{rpm}$ for $5 \mathrm{~s}$ and in the $2^{\text {nd }}$ step at 3500 $\mathrm{rpm}$ for $35 \mathrm{~s}$. After spin coating, the film was preheated to $250^{\circ} \mathrm{C}$ for $5 \mathrm{~min}$ over a hot plate to evaporate the solvent and remove the organic residuals. The coating step was repeated ten times to obtain the desired thickness. After deposition of the last coating, the films were placed into a furnace and annealed in ambient atmosphere at temperatures ranging from $400 \sim 600^{\circ} \mathrm{C}$ for $30 \mathrm{~min}$.

Fig. 1 shows the flowchart showing the procedure for preparing $\mathrm{Al}$ doped $\mathrm{ZnO}$. The films were coated on glass substrates for the optical measurements and on $\mathrm{Si}$ for examining the morphology and structure. The morphology of the $\mathrm{Al}$ doped $\mathrm{ZnO}$ films was observed by field emission scanning electron microscopy (FE-SEM, JEOL JSM7401F). The crystal structure of the $\mathrm{Al}$ doped $\mathrm{ZnO}$ films was determined by X-ray diffraction (XRD, Philips xpert system). The optical properties of $\mathrm{ZnO}$ films were measured by UV-VIS-NIR spectrophotometry (SHIMADZU, UV-3150).
The electrical resistance was measured using a four point probe method (CHANG MIN TECH CO. LTD., CMT-SR $2000 N)$.

\section{Results and Discussion}

Fig. 2 shows FE-SEM images of $\mathrm{ZnO}$ films. The $\mathrm{ZnO}$ films were deposited using a sol-gel process. Fig. 2(a) showed that the undoped $\mathrm{ZnO}$ film was porous. Preheating the $\mathrm{ZnO}$ film to $250^{\circ} \mathrm{C}$ resulted in the partial decomposition and removal of the solvent and organic substances from the precursor. The top surface of the $\mathrm{ZnO}$ film could be observed clearly. The film thickness can be affected by the viscosity of the solution in sol-gel method with spin-coating and the ionic radius. From the view point of ionic radius, it was expected that the thickness of the $\mathrm{Al}$ doped $\mathrm{ZnO}$ films would be thinner than the undoped $\mathrm{ZnO}$ film, because $\mathrm{Al}^{3+}(0.54 \AA)$ has a smaller ion radius than $\mathrm{Zn}^{2+}(0.74 \AA)$. However, the cross section images in Fig. 3 (b), (c) show that the $\mathrm{Al}$ doped and undoped $\mathrm{ZnO}$ films have similar thickness $(100 \mathrm{~nm})$ with no pores. Al doped and undoped $\mathrm{ZnO}$ films were quite uniform and compact.

Fig. 3 shows the XRD pattern of $3 \mathrm{~mol} \% \mathrm{Al}$ doped $\mathrm{ZnO}$ films annealed at temperatures ranging from $400^{\circ} \mathrm{C}$ to $600^{\circ} \mathrm{C}$ for $30 \mathrm{~min}$. Fig. 3 shows three principal peaks, (100), (002) and (101), corresponding to the wurzite lattice. The $3 \mathrm{~mol} \% \mathrm{Al}$ doped $\mathrm{ZnO}$ films had a polycrystalline structure. The XRD pattern showed a strong peak of $34.42^{\circ} 2 \theta$ due to the $\mathrm{ZnO}(002)$ crystal plane and a weak peak at $31.77^{\circ}$ and $36.25^{\circ} 2 \theta$ due to $\mathrm{ZnO}(100)$ and (101) crystal planes, which are in accordance with the JCPDS card no. 36-1451 with lattice constants of $\mathrm{a}=3.25 \AA$ and $\mathrm{c}=5.21 \AA$. The intensity of the (002) peak increased with increasing the annealing temperature up to $600^{\circ} \mathrm{C}$ (Fig. 3(a)). The (002) peak intensity was increased most significantly by heating. The other peaks remained relatively

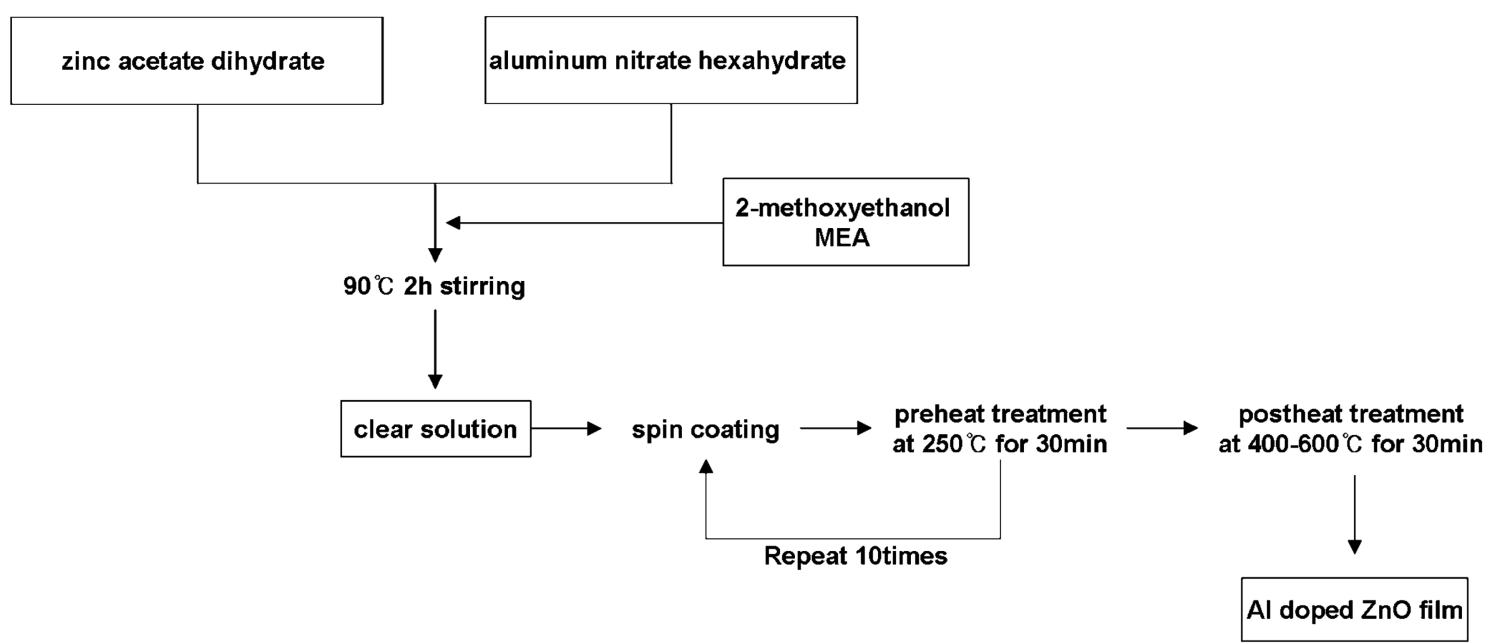

Fig. 1. Outline of the fabrication process for the deposition of $\mathrm{Al}$ doped $\mathrm{ZnO}$ films. 

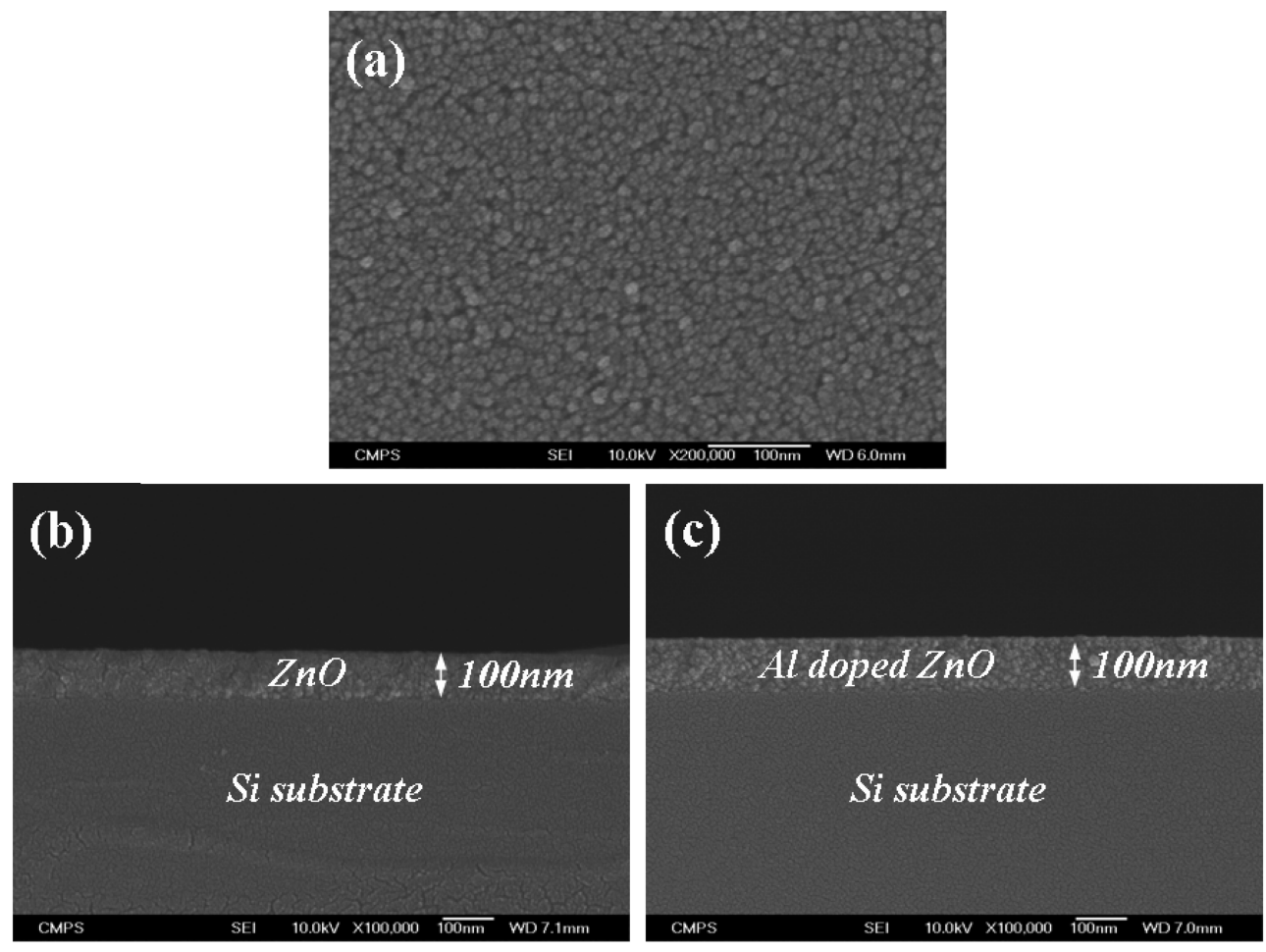

Fig. 2. Plain view and cross section FE-SEM image of $\mathrm{ZnO}$ films fabricated using sol-gel process. (a) Low magnification image showing the undoped $\mathrm{ZnO}$ film, (b) cross section image of the undoped $\mathrm{ZnO}$ film, (c) cross section image of the 1 mol\% $\mathrm{Al}$ doped $\mathrm{ZnO}$ film.

constant. The increase in (002) peak intensity indicates improvement in the crystalline quality with increasing annealing temperature to $600^{\circ} \mathrm{C}$.

Fig. 4 shows XRD patterns of the $\mathrm{ZnO}$ thin films annealed at $600^{\circ} \mathrm{C}$ with different $\mathrm{Al}$ doping concentrations. It is found that the position of (002) peak is shifted to higher angle side for the Al-doped $\mathrm{ZnO}$. The intensity of the (002) peak for the $\mathrm{Al}$ doped $\mathrm{ZnO}$ films decreased with increasing doping concentration. This indicates that an excess of dopant deteriorates the crystal of the $\mathrm{ZnO}$ films, which may be due to the increased compressive stress in the films from the difference in ionic radius between $\mathrm{Al}^{3+}$

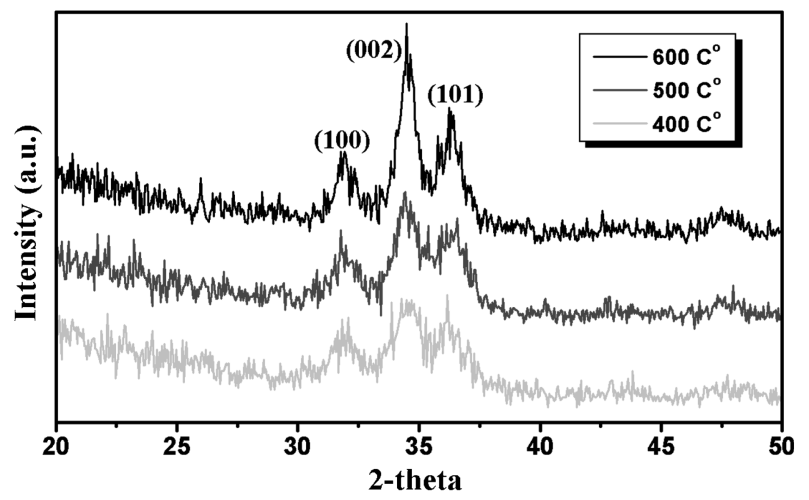

Fig. 3. XRD patterns of $3 \mathrm{~mol} \% \mathrm{Al}$ doped $\mathrm{ZnO}$ thin films deposited on $\mathrm{Si}$ substrates using a sol-gel process and annealed at temperatures ranging from $400^{\circ} \mathrm{C}$ to $600^{\circ} \mathrm{C}$ for $30 \mathrm{~min}$.
$(0.54 \AA)$ and $\mathrm{Zn}^{2+}(0.74 \AA)$ as well as dopant segregation in the grain boundaries at high doping concentrations.

Fig. 5 shows FE-SEM images of undoped and $3 \mathrm{~mol} \%$ $\mathrm{Al}$ doped $\mathrm{ZnO}$ films annealed at temperatures ranging from $400^{\circ} \mathrm{C}$ to $600^{\circ} \mathrm{C}$. The film structure consists of many round shaped particles. The surface morphology of the $\mathrm{ZnO}$ films revealed a remarkable transformation. The grains of the undoped and $3 \mathrm{~mol} \% \mathrm{Al}$ doped $\mathrm{ZnO}$ films become larger and more densely packed with increasing annealing

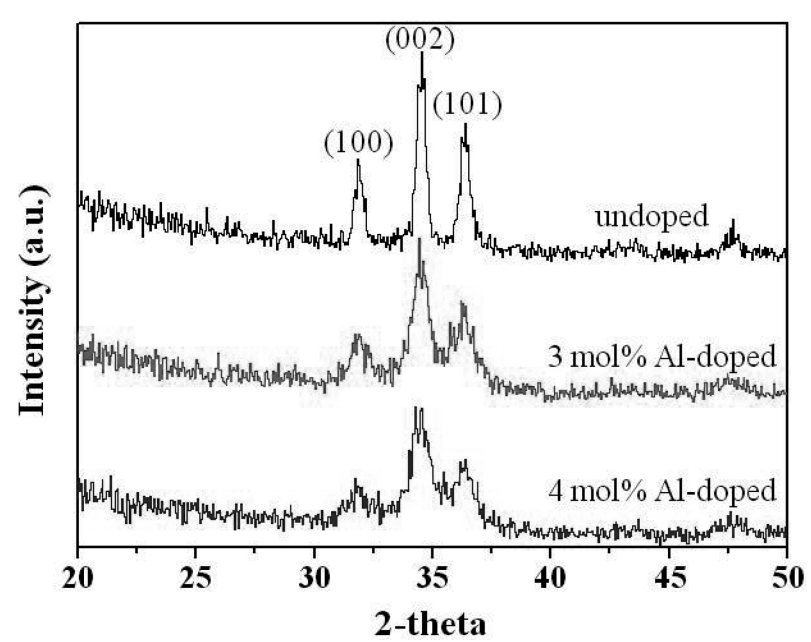

Fig. 4. $\mathrm{XRD}$ patterns of $\mathrm{ZnO}$ thin films annealed at $600^{\circ} \mathrm{C}$ with undoped, 3 and $4 \mathrm{~mol} \% \mathrm{Al}$ doping concentration. 


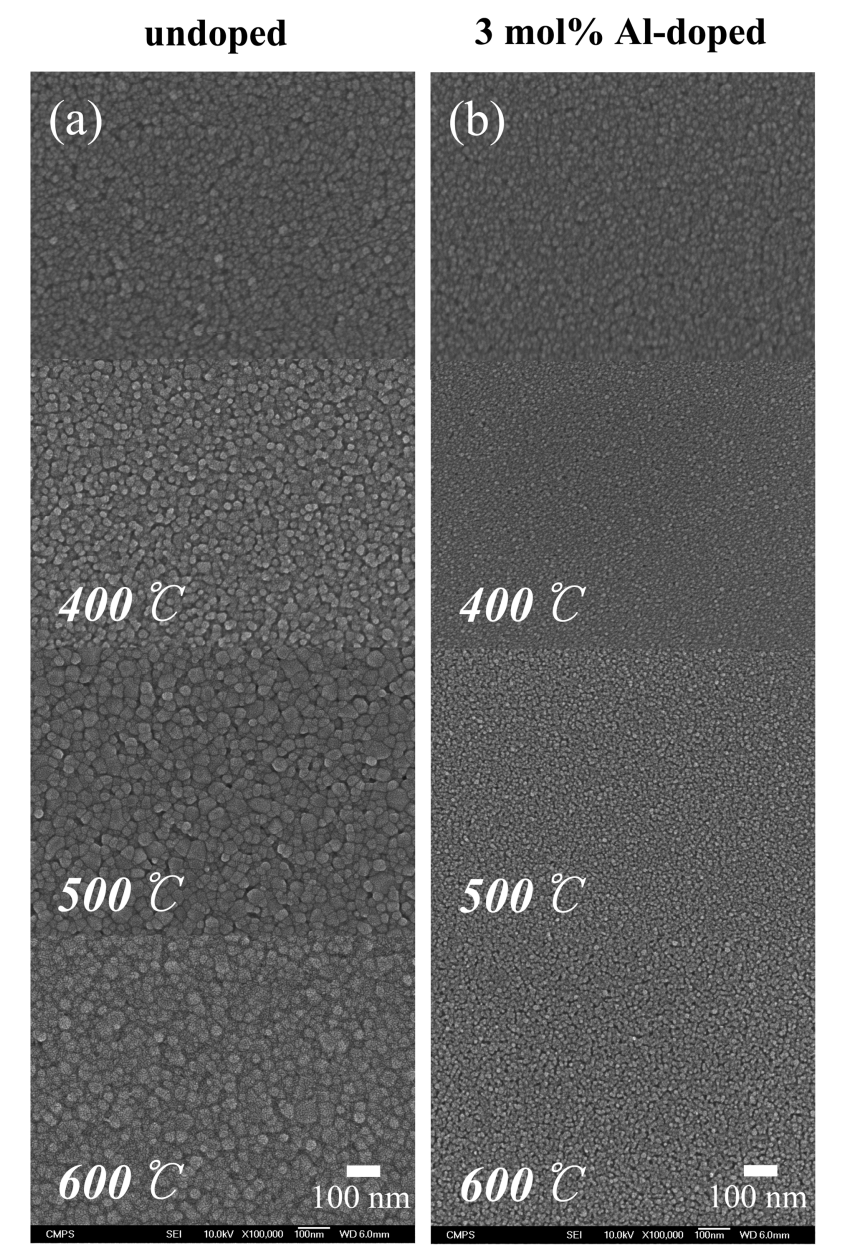

Fig. 5. Plain view FE-SEM image of (a) undoped and (b) $3 \mathrm{~mol} \%$ $\mathrm{Al}$ doped $\mathrm{ZnO}$ thin films surface annealed at temperatures ranging from $400^{\circ} \mathrm{C}$ to $600^{\circ} \mathrm{C}$.

temperature. However, the undoped $\mathrm{ZnO}$ films showed denser packing than the $3 \mathrm{~mol} \% \mathrm{Al}$ doped $\mathrm{ZnO}$ films. The particle size of the $3 \mathrm{~mol} \% \mathrm{Al}$ doped $\mathrm{ZnO}$ film was smaller than that of the undoped $\mathrm{ZnO}$ film. The particle size of the $\mathrm{Al}$ doped $\mathrm{ZnO}$ film decreased with increasing doping concentration. This is because grain growth had been disturbed by compression stresses due to the difference in ionic radius between $\mathrm{Al}^{3+}(0.54 \AA)$ and $\mathrm{Zn}^{2+}(0.74 \AA){ }^{16)}$ These results show that doped $\mathrm{ZnO}$ film has poorer crystallinity than the undoped films. This is consistent with the fact observed from the XRD pattern shown in Fig. 4.

Fig. 6 shows the corresponding optical transmittance spectra of $\mathrm{ZnO}$ films with different $\mathrm{Al}$ doping concentrations. The optical transmittance of all $\mathrm{ZnO}$ films were $>87 \%$ in the visible and near infrared wavelength regions (glass substrate). The $\mathrm{Al}$ doped $\mathrm{ZnO}$ films produced in this study by sol-gel process exhibited good optical properties. The transmittance of the blue region was higher than that of the red region. The $4 \mathrm{~mol} \%$ doped $\mathrm{ZnO}$ film showed the highest transmittance. The inside of the film

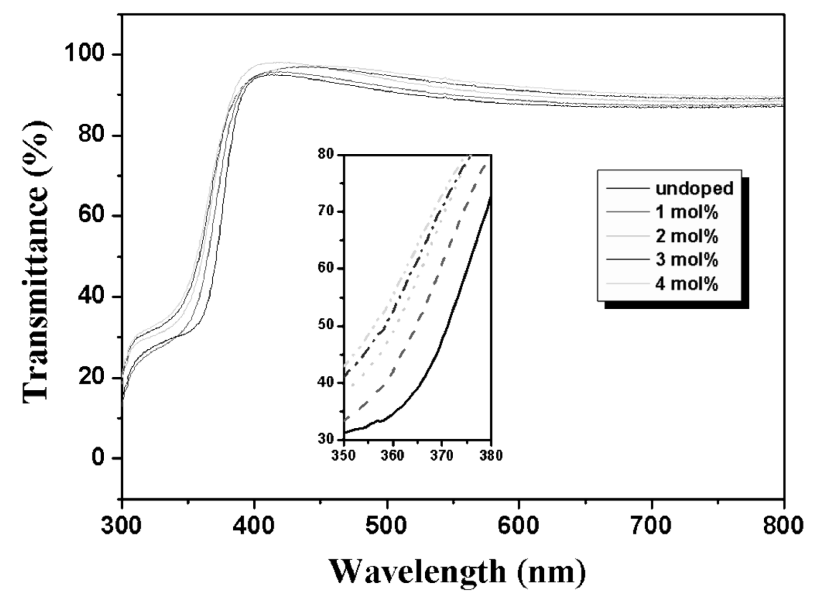

Fig. 6. The transmittance spectra of the undoped and $\mathrm{Al}$ doped $\mathrm{ZnO}$ films on glass substrates with different $\mathrm{Al}$ doping concentrations.

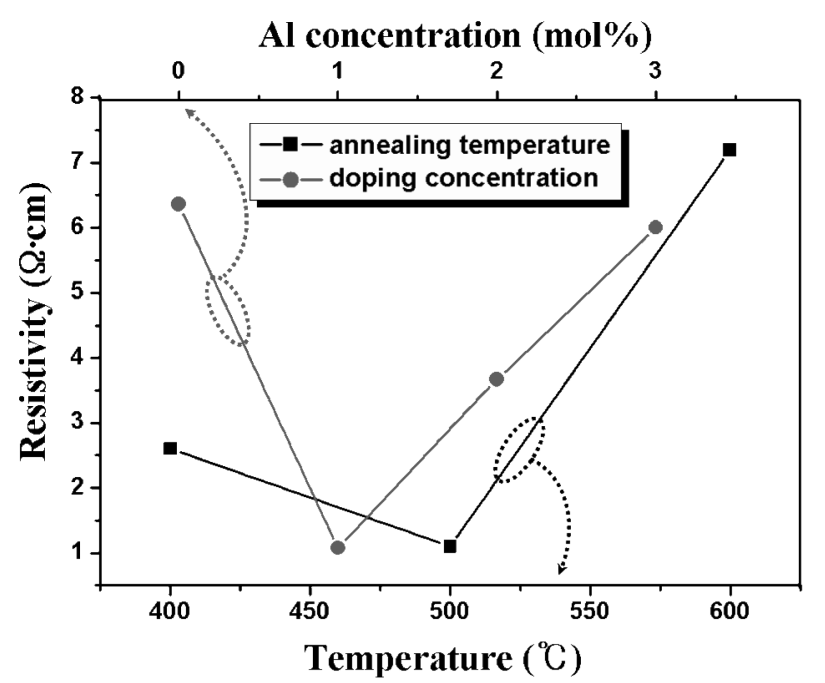

Fig. 7. Electrical properties of $\mathrm{Al}$ doped $\mathrm{ZnO}$ films as a function of the $\mathrm{Al}$ doping concentrations (at $500^{\circ} \mathrm{C}$ ) and annealing temperatures (at $1 \mathrm{~mol} \% \mathrm{Al}$ ).

decreased the light diffused due to increase in grain density. The absorption edge was observed at approximately 370 $\mathrm{nm}$, which is similar to the band gap of $\mathrm{ZnO}(3.37 \mathrm{eV})$. The absorption wavelength showed a blue-shift with increasing doping concentration, indicating that the band gap of the $\mathrm{ZnO}$ films increases with increasing doping concentration.

This might be due to the Burstein-Moss effect (The bottom of the valance band is full of electrons with increasing doping concentration, and the electron of the valance band requires an excess of energy to excite conduct band.), which describes the blue-shift in the absorption edge of a degenerate semiconductor with increasing carrier concentration. $^{17,18)}$

Fig. 7 shows the electrical properties of the $\mathrm{ZnO}$ films as the function of the $\mathrm{Al}$ doping concentrations annealed at $500^{\circ} \mathrm{C}$ for $30 \mathrm{~min}$ and the annealing temperature with 
$1 \mathrm{~mol} \% \mathrm{Al}$ doping. The lowest resistivity of $\mathrm{Al}$ doped $\mathrm{ZnO}$ films was obtained at $1 \mathrm{~mol} \% \mathrm{Al}$ doped $\mathrm{ZnO}$ films. It is usually known that $\mathrm{ZnO}$ is a n-type semiconductor in which the major carrier is an electron. A comparison of the $\mathrm{Al}$ doped and undoped $\mathrm{ZnO}$ films showed that the decrease in electrical resistivity at initial doping concentration might be due to an increase in carrier concentration. However, the increase in electrical resistivity with further increases in doping concentration might be due to a decrease in the carrier mobility caused by dopant segregation at the grain boundary. In Fig. 7, the $\mathrm{ZnO}$ films annealed at $500^{\circ} \mathrm{C}$ showed the lowest resistivity at $1 \mathrm{~mol} \% \mathrm{Al}$ doped $\mathrm{ZnO}$ films. Consequently, the doping concentration and thermal treatment are important factors in an electrical conductivity of $\mathrm{ZnO}$ films.

\section{Conclusion}

Transparent conducting aluminum doped $\mathrm{ZnO}$ thin films were deposited using a sol-gel process. The dopant concentration was varied from 1 to $4 \mathrm{~mol} \%$. The thickness of the Al doped and undoped $\mathrm{ZnO}$ films was similar $(100 \mathrm{~nm})$ with no pores. Al doped and undoped $\mathrm{ZnO}$ films are very uniform and compact. The (002) peak intensities of the Al doped $\mathrm{ZnO}$ films decreased with increased dopant concentration due to the increased compressive stress in the films caused by the difference in ionic radius between $\mathrm{Al}^{3+}$ $(0.54 \AA)$ and $\mathrm{Zn}^{2+}(0.74 \AA)$ as well as dopant segregation in the grain boundaries at high doping concentrations. The grains of undoped and $3 \mathrm{~mol} \% \mathrm{Al}$ doped $\mathrm{ZnO}$ films became larger and more densely packed with increasing annealing temperature. The optical transmittance of all $\mathrm{ZnO}$ films was $>87 \%$ in the visible and near infrared wavelength region. The absorption wavelength showed a blue-shift with increasing doping concentration. The band gap of the $\mathrm{ZnO}$ films increased with increasing doping concentration. The $\mathrm{ZnO}$ films annealed at $500^{\circ} \mathrm{C}$ showed the lowest resistivity at $1 \mathrm{~mol} \% \mathrm{Al}$ doping. The deposition process in this study requires no expensive and precise vacuum equipment, and allows large scale fabrication of $\mathrm{Al}$ doped $\mathrm{ZnO}$ films at a relatively low cost. These $\mathrm{Al}$ doped $\mathrm{ZnO}$ films are expected to have a large number of applications in display, electrical and optical devices.

\section{Acknowledgement}

This study was supported by the SRD/ERC program of MOST/KOSEF (R11-2005-048-00000-0) and the Research Program 2009 of Kookmin University in Korea.

\section{References}

1. J. B. Baxter and E. S. Aydil, App. Phy. Lett., 86, 0531141-3 (2005).

2. N. Saito, H. Haneda, T. Sekiguchi, N Ohashi, I. Sakaguchi and K. Koumoto, Adv. Mater., 6, 418 (2002).

3. S. Liang, H. Sheng, Y. Liu, Z. Huo, Y. Lu and H. Shen, J. Cryst. Growth, 225, 110 (2001).

4. J. Y. Lee, Y. S. Choi, J. H. Kim, M. O. Park and S. Im, Thin Solid Films, 403-404, 553 (2002).

5. G. G. Valle, P. Hammer, S. H. Pulcinell and C. V. Sanrilli, J. Eur. Ceram. Soc., 24, 1009 (2004).

6. T. J. Hsueh, C. L. Hsu, S. J. Chang, P. W. Guo, J. H. Hsieh and I. C. Chen, Scripta Materialia, 57, 53 (2007).

7. S. J. Tark, M. G. Kang and D. Kim, Kor. J. Mat. Res., 16(7), 449, (2006) (in Korean).

8. G. Alvarez, J. J. Flores, J. O. Aguilar, O.Gómez-Daza, C. A. Estrada, M. T. S. Nair and P. K. Nail, Solar Energy, 78, 113 (2005).

9. A. E. Morales, M. H. Zaldivar, U. Pal, Optical Materials, 29, 100 (2006).

10. H. Gomez, A. Maldonado and D. R. Acosta, Sol. Energ. Mater. Sol. Cell., 87, 107 (2005).

11. J. H. Choi, H. Tabata and T. J. Kawai, J. Cryst. Growth, 226, 493 (2001).

12. A. El-Shaer, A. Che Mofor, A. Bakin, M. Kreye and A. Waag, Superlattice Microst., 38, 265 (2005).

13. Y. J. Cho, A. Park and C. Lee, Kor. J. Mat. Res., 16(7), 445 (2006) (in Korean).

14. A. W. Ott and R. P. H. Chang, Mater. Chem. Phys., 58, 132 (1999).

15. R. Kaur, A. V. Singh and R. M. Mehra, J. Non-Cryst. Solids, 352, 2335 (2006).

16. Z. Q. Xu, H. Deng, Y. Li, H. Cheng, Mater. Sci. Semicond. Process., 9, 132 (2006).

17. M. J. Alam and D. C. Cameron, J. Vac. Sci. Technol. A, 19, 1642 (2001).

18. B. E. Sernelius, K. F. Berggren, Z. C. Jin, I. Hamberg and C. G. Granqvist, Phys. Rev. B, 37, 10244 (1988). 